клініко-лабораторний ефект в еутиреозі (зниження рівня тиреоглобуліну в середньому на 28,3\% - 3 1,282 55,4 до 0,364 $\pm 0,75$ нг/мл; антитіл до

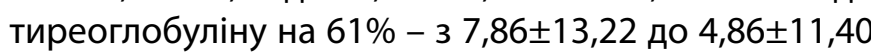
МО/мл за 3 місяці), та стійку ремісію захворювання за результатами УзД шиї (відсутність кровотоку, зменшення розмірів уражених лімфатичних вузлів у 6 хворих, та відсутність метастатичного ураження у 7 обстежених хворих). Отримані результати свідчать про високу ефективність описаного методу лікування метастатичної хвороби (позитивний ефект у $81,3 \%$ пролікованих хворих).

Висновки. Через технічні складнощі та підвищений ризику розвитку ускладнень, що часто виникають при повторній операції, необхідно зменшити кількість оперативних втручань до мінімуму. За наявності рецидиву захворювання етанолова деструкція метастатичних лімфовузлів дозволяє відмовитись від повторного оперативного втручання, має низький ризик ускладнень та високу економічну доцільність.

\section{ЛITEPATУРA}

1. Heilo A, Sigstad E, Fagerlid KH, Håskjold Ol. Efficacy of Ultrasound-Guided Percutaneous Ethanol Injection Treatment in Patients with a Limited Number of Metastatic Cervical Lymph Nodes from Papillary Thyroid Carcinoma. The Journal of Clinical Endocrinology \& Metabolism. 2011 Sept; Vol. 96(9):2750-5.

2. Hay ID, Charboneau JW. The Coming of Age of Ultrasound-Guided Percutaneous Ethanol Ablation of Selected Neck Nodal Metastases in WellDifferentiated Thyroid Carcinoma. The Journal of Clinical Endocrinology \& Metabolism. 2011 Sept; 96(9):2717-20.

3. Jeon MJ, Kim WG, Choi YM, Kwon H, Song DE. Recent Changes in the Clinical Outcome of Papillary Thyroid Carcinoma with Cervical Lymph Node Metastasis. The Journal of Clinical Endocrinology \& Metabolism. 2015 Sept; 100(9):3470-7.

Дата надходження до редакиії 05.11.2018 p.

https://doi.org/10.24026/1818-1384.4(64).2018.150187

\title{
РОЛЬ МЕТАБОЛІЧНОЇ ХІРУ РГІЇ У ЛІКУВАННІ ЦУКРОВОГО ДІАБЕТУ 2 ТИПУ: МОЖЛИВОСТІ, ПРОБЛЕМИ ТА ПЕРСПЕКТИВИ
}

\author{
В.М. Лисенко, М.Ю. Крестянов, А.Ю. Глаголсва, \\ Д.С. Завертиленко \\ Кафедра хірургії та судинної хірургї̈ НМАПО імені П.Л. Шупика
}

Вступ. Захворюваність та поширеність цукрового діабету в Україні та світі протягом останніх 10 років зберігає стійку тенденцію до збільшення. Кількість дорослих із вказаним станом зросла зі 108 мільйонів у 1980 році до 422 мільйонів у 2014 році. Прогнозується, що до 2030 року цукровий діабет стане сьомою провідною причиною смерті серед населення світу [1]. Ожиріння $\epsilon$ основним незалежним фактором ризику розвитку цукрового діабету 2 типу-більшеніжу $90 \%$ хворих реєструється надмірна маса тіла або ожиріння різного ступеня [2]. Нормалізація маси тіла та фармакологічна корекція гіперглікемії забезпечують задовільну компенсацію цукрового діабету 2 типу, однак, відсоток часткової або повної тривалої ремісії зазначеного захворювання (більше 7 років) при модифікації способу життя та медикаментозному лікуванні дуже низький $(0,007-1,47 \%)$ [3]. На сьогодні акумульовано значну доказову базу стосовно ефективності баріатричних хірургічних втручань як у довгостроковій стабілізації глікемії, так і в корекції патологічних змін при метаболічному синдромі в цілому.

Мета - аналіз та узагальнення літературних даних щодо можливості досягнення тривалої ремісії цукрового діабету 2 типу при застосуванні баріатричних операцій.

Методи. Проведено аналіз баз даних Medline, PubMed та Cochrane database.

Результати. Відсоток ремісії цукрового діабету 2 типу після баріатричних операцій становить від 76,8\% до 92\% [4]. Потенційними механізмами, що нормалізують гомеостаз глюкози після вказаних втручань, $\epsilon$ зміна кишкового мікробіому через транслокацію мікрофлори при шунтуючих операціях, підвищення продукції жовчних кислот та 
фактору росту фібробластів 19 (FGF19), нормалізація нейрогуморальної регуляції функції травного тракту (рівні греліну та GLP-1), зниження синтезу тригліцеридів, репрограмування процесу кишкової абсорбції глюкози тощо [5]. Окрім нормалізації рівня глікемії, баріатричні операції сприяють покращенню функції нирок при діабетичній гломерулопатії, зниженню ризику мікро- та макросудинних ускладнень. Субаналіз дослідження STAMPEDE показав, що баріатричні втручання зменшують ступінь пошкодження підшлункової залози, знижують рівні $\mathrm{HbA}_{1 c^{\prime}}$ підвищують чутливість тканин до інсуліну та покращують роботу бета-клітин. 3 134 пацієнтів, яких спостерігали протягом 5 років, середній показник $\mathrm{HbA}_{1 c}$ на початку дослідження становив $9,2 \pm 1,5 \%$, рівень $\mathrm{HbA}_{1 С}<6 \%$ без додаткової терапії був досягнутий у $29 \%$ пацієнтів після обхідного шлункового шунтування (14 349$)$ і у 23\% пацієнтів після рукавної резекції (11 з 47). Серед пацієнтів, які отримували тільки цукрознижувальну терапію, компенсація рівня глікемії спостерігалась лише у $5 \%$ (2 з 38) [6].

Згідно 3 The Diabetes Surgery Summit II Guidelines, баріатричні втручання рекомендовані пацієнтам 3 цукровим діабетом 2 типу та IMT $\geq 40 \mathrm{kr} / \mathrm{M}^{2}$ незалежно від ефективності контролю глікемії, а також пацієнтам 3 діабетом та IMT 35-39,9 кг/ $/ \mathrm{M}^{2}$ за неможливості досягнення контролю глікемії завдяки дієті і медикаментозному лікуванню [7].

Висновки. Баріатрична хірургія $\epsilon$ перспективним напрямком комбінованого лікування метаболічних порушень з тривалим збереженням результату при цукровому діабеті 2 типу. Необхідні подальші дослідження для визначення оптимальної тактики при рецидивах ожиріння та цукрового діабету після баріатричних операцій.

\section{ЛITEPATУPA}

1. Ang GY. Reversibility of diabetes mellitus: Narrative review of the evidence. World J Diabetes. 2018; 9(7):127-131.

2. World Health Organization. Obesity and Overweight Fact Sheer. Accessed from http://www.who.int/ dietphysicalactivity/media/en/gsfs_obesity.pdf October 2013

3. Karter AJ, Nundy S, Parker MM, Moffet HH, Huang $E S$. Incidence of remission in adults with type 2 diabetes: the diabetes \& aging study. Diabetes Care. 2014; 37:3188-3195.

4. Chang SH, Stoll CR, Song J, Varela JE, Eagon CJ, Colditz $G A$. The effectiveness and risks of bariatric surgery: an updated systematic review and meta-analysis, 2003-2012. JAMA Surg. 2014; 149:275-287.

5. Batterham RL, Cummings DE. Mechanisms of Diabetes Improvement Following Bariatric/ Metabolic Surgery. Diabetes Care. 2016; 39:893-901.

6. Schauer PR, Bhatt DL, Kirwan JP, Wolski K, Aminian $A$, Brethauer $S A$, et al; STAMPEDE investigators. Bariatric Surgery versus Intensive Medical Therapy for Diabetes - 5-Year Outcomes. N Engl J Med 2017; 376:641-51.

7. Cohen RV, Shikora S, Petry T, Caravatto PP, Le Roux $C W$. The Diabetes Surgery Summit II Guidelines: a Disease-Based Clinical Recommendation. Obes Surg. 2016 Aug; 26(8):1989-91.

Дата надходження до редакиії 31.10.2018 p.

https://doi.org/10.24026/1818-1384.4(64).2018.150188

\title{
ВПЛИВ СОЦАЛЬНОГО СТАТУСУ НА РЕЗУЛЬТАТИ ЛІКУВАННЯ ПАЦІЕНТІВ ІЗ ЦУКРОВИМ ДІАБЕТОМ 2 ТИПУ ТА СИНДРОМОМ ДІАБЕТИЧНОЇ СТОПИ
}

\author{
О.В. Марченко \\ Український науково-практичний иентр ендокринної хірургії, трансплантаиії \\ ендокринних органів і тканин МОЗ України
}

Синдром діабетичної стопи (СДС) $\epsilon$ найбільш соціально значущим ускладненням цукрового діабету (ЦД) в усьому світі. Розвивається це вкрай небезпечне ускладнення майже у кожного шостого пацієнта із цукровим діабетом.
Мета: оцінка впливу соціального статусу хворих із СДС (проживання з родиною, часткове перебування під наглядом родичів, самотність) на перебіг хвороби.

Матеріал і методи. Під спостереженням 